\title{
The Impact of the Covid-19 Epidemic on Saudi Stock Market Performance Using a Regression Model and Granger Causality Test-Empirical Analysis
}

\author{
Dr. Kavita Panjwani \& Dr. Mohammad Arif Riaz \\ Finance and Banking Department \\ College of Business Administration \\ Jazan University, Jazan \\ Kingdom of Saudi Arabia (K.S.A)
}

Received: April 5, $2021 \quad$ Accepted: June 1, $2021 \quad$ Published: June 1, 2021

doi:10.5296/ajfa.v13i1.18664 URL: https://doi.org/10.5296/ajfa.v13i1.18664

\begin{abstract}
The objective of the study to investigates the impact of COVID-19 epidemic on Saudi stock market performance by using regression model and pairwise granger causality tests. The time series data has been taken for this study from 01 March 2020 to 6 Dec 2020. Coronavirus has been measured in terms of cumulative new corona cases per million, new corona deaths per million, total corona cases per million and total corona deaths per million, whereas stock market return is evaluated in terms of stock market index. The study's finding reveal that Saudi stock market significance affected by COVID-19. The study also depicts that unidirectional and bidirectional relationship between corona-virus cases and Saudi stock market with the help of granger causality test. We also highlight the main the preventive policies taken by governments related to COVID-19 have affected the stock market.
\end{abstract}

Key words: Corona-virus, Market return, Stock market index, Time series, unidirectional. 


\section{Introduction}

An unexpected outbreak of COVID-19 spread globally towards the end of year 2019. Wuhan, a Chines city center, has been designed as the primary COVID-19 event for December 2019. Since early January 2020, an epidemic has been spreading silently to different regions of China because of a mass of migration during the new years of China and the Wuhan Geographical Area, as a major transport hub. The initial three out-of-Wuhan cases were reported on 19 January. On 23 January, at 10:00 am in Wuhan, the ship and large-distance passenger traffic were suspended. As a further safety precaution, each exit and flight train were cancelled. In order to prevent pesticides from being made more popular, the Chinese government continues to pursue other welfare initiative, for example travel ban, curfews and end of school. The World Health Organization issued the first worldwide warning for epidemic on 30 January 2020 (WHO2020a). The total overall confirmed cases around the worldwide proclaimed a pandemic on 11 March 2020. (WHO2020b). Flare-up focus has gradually been shifting from China to Europe and America. The global pandemic was confirmed by the World Health Organization (WHO) COVID-19 on 11 March 2020. Consequently, it is a significant reminder for all nations since it presents additionally a genuine danger to general wellbeing and by and large economy on both public and global level. Coronavirus' monetary impacts are not just extensive but rather decidedly destructive as much as they caused perpetual business sectors conclusion, long haul work misfortunes in the midst of this pandemic, and so on the flow Coronavirus has widegoing and critical stun waves on monetary market that is comprised of obligation, commodity (crude oil and gold) and securities exchanges.

The economic disruption caused by the pandemic has dramatic effects on stock markets, particular stock, defense, and material (such as crude oil and gold) markets, making prediction a far more difficult task during the pandemic. Significant events in March 2020 included a suspected Russia-Saudi Arabia oil cost war as a result of the failure to negotiate an OPEC+ settlement, resulting in oil prices falling and a stock market crashes. Many economic implications of the coronavirus pandemic, which is part of the coronavirus recession, is financial market consequences. Stock return or securities exchange forecast is a significant exploration subject that has pulled in re-searchers' consideration for a long time. stock market around the world hit badly with this pandemic and many big companies struggling to survive in the COVID19 times. It's turned out to be a lot harder job for analyst to foresee the market movement effectively. Prediction is an actual act of indicating that something will happen in the future with lot of confidence that can influence the market sentiments by having limited access to the information. COVID-19's pandemic affected world financial markets. Continuous changes to economic growth predictions, as well as rising risk aversion, have led in extreme volatility in the stock market and other risky asset markets, accompanied by severe uncertainty about future pandemic development. By the end of February 2020, financial markets reached the risk-aversion stage, with market volatility considerably enhanced. Stock markets began to fall rapidly, with sales dropping by about 30 percent of their market value in weeks, faster than during the 2008 global financial crisis. Overall, stock markets reacted unfavourably due to pandemic but recovered marginally by announcing the rescue scheme (Rahman, et al. 2021). Consequently, The financial market's reaction to the COVID-19 epidemic is noteworthy. 
Stock market returns prediction is one of the most testing position because of numerous components that associated with the market prediction for example interest, politics, and economic growth that make the stock market volatile and difficult to predict precisely. Principle aims to anticipate the future market movement of the financial markets will prompt more benefit investor can make. Firstly, the importance of study to investigates the effect of epidemic on Saudi stock market performance by using regression model and pairwise granger causality tests. by using regression model. Secondly, pairwise granger causality tests also depict unidirectional and bidirectional relationship between corona-virus and Saudi stock market. Thirdly, the remaining paper is organized such as data collection, Model and technique can be found in the next section. In the following, the empirical results are described and analysed. The final section of the report includes conclusion and policy prevention.

\section{Literature Review}

The coronavirus (COVID-19) is a global epidemic with unclear origins, a scarcity of targeted treatments, and limited therapeutic competence. Every country is responding to the pandemic, which is wreaking havoc on the global economy and financial markets (Aslam et al., 2020). As a result, studying the economic effects of the pandemic is a hot topic that has recently piqued the interest of researchers (Liu et al., 2020). The stock market has the potential to be an extremely powerful economic tool. It provides a unique perspective on a company's and the economy's future prospects. This is because the value of a corporation is generated by all future cash flows, which are now reduced to take time and uncertainty into consideration (Wagner, 2020). The literature on Coronavirus's effects on the worldwide stock market is fast growing. While the stock market's behavior during the epidemic may appear arbitrary, irrational, or even insane at first glance, a closer look indicates that they did not act haphazardly (CapelleBlancard \& Desroziers, 2020). During COVID-19, stock market swings reflected emotions rather than substance (Cox et al., 2020). Several analyses have linked the COVID-19 epidemic to an unprecedented economic and financial disaster. Global financial market risks have surged as a consequence of the COVID-19 outbreak (Zhang et al., 2020). The majority of empirical investigations revealed that the expansion of the coronavirus outbreak harmed stock market indices. (Cao et al., 2020; Ashraf, 2020; Alber, 2020; Rahman et al., 2021; Ahmar \& del Val, 2020; Anh \& Gan, 2020; Eleftheriou \& Patsoulis, 2020; Shujan et al., 2020; Camba \& Camba Jr, 2020).

Olatunji, Al-Ahmadi, Elshafei and Fallatah (2013) suggested that methodology is based on historical information from long-term stock markets. They employed inventory closing price as a variable for input devices. The optimal value is found via experimental simulation based on data from the day before the closing prices are estimated on the following day. The coefficient includes the R2, root mean squared error and average absolute defect (MAD) and the MAPE to quantify efficiencies in the proposed Artificial Neutral Network (ANN) Saudi stock price forecast (MAPE).The analysis conclude that the proposed ANN model forecasts a very low RMSE (1.8174), an extremely low MAD of 18.2835, an extremely low MAPE (1.6476) and a strong correlation factor of up to $99.9 \%$ of the sample to the test next day, suggesting that the model reliably predicts and mimics the market trend in its predictions. 
V Kranthi and Sai Reddy (2018) establish a Machine Learning (ML) approach to prediction in their research. The system, which is derived from available stock data, gathers information and applies the knowledge gained to make predictions. In their analysis, they use Vector Machine Support (SVM) and Radial Base Function (RBF) for bond prediction. Their research concludes that numerical results suggest a high degree of efficiency in effective stock market forecasting.

Vijha, Chandolab, Tikkiwalb, and Kumarc (2019) explained using random forest methods and artificial neural network for predicting a closing cost of five businesses in different industries the following day. For the modeling of new variables, financial data such as open, high, low, inventory closed prices are used. Normal strategic metrics like the RMSE and MAPE are used to evaluate the models. They conclude that, in order to improve the precision of the forecast price value, new variables were generated by combining existing variables. ANN is used to forecast the stock's following day closing price, while RF is utilized for a comparative study. An identical RMSE, MAPE, and MBE values research clearly reveals that ANN delivers better stock price forecasting compared to RF.

Chaouachi, M., \& Slim, C. (2020). described using a cointegration methodology for Autoregressive Distributed Lag (ARDL), this research finds out the pandemic result on the Saudi stock market. More particularly, this research shows the relation between the Tadawul All Shares Index (TASI) natural logarithm trading volume and the COVID-19 natural logarithm validated in both short and long-term cases. Cointegration boundary test is performed on daily basis series. The causality test is used to determine variable relationships. Our findings show that pandemic has a long-term adverse influence on financial market. The causality test reveals the unidirectional relationship. The robustness test seems conclusive.

He.D., D.J., Yu, S.J. (2020). This article discusses the immediate effect on the financial markets and the COVID-19 disaster. Empirical research depicts that the effect of coronavirus on share price of afflicted nations is negative, albeit short-term, through ordinary t-testing and Chisquare test such as Mann-Whitney testing. On the other hand, it doesn't seem in these countries to have a greater effect than the global average on financial markets. According to the findings, coronavirus is influencing the economic effect of the pandemic on other countries' financial markets. The findings also serve as a basis to track global stock market trends and boost the global economy.

Alam, M. N., Alam, M. S., \& Chavali, K. (2020). This paper examined the lock-down effect of coronavirus on the Indian stock market was specified. This study assessed the influence of lockout on the Indian stock market and if the market reaction before and after COVID-19 would be the same. Research approach is used for the Market Model Event. A sample of 31 Bombay Stock Exchange-listed companies was chosen at random (BSE). The occasion was a formal lockdown announcement. The results show that the average lockdown predicted by Abnormal Returns and investors was a highly positive market response during the current lockdown period; however, investors panicked before to the lockdown and generated a negative AAR. The study shows that the current lock-down period is AR, showing that until the situation in India improves, the lock-down has a favourable impact on stock market performance. 


\section{$\Lambda$ Macrothink}

Asian Journal of Finance \& Accounting

ISSN 1946-052X

2021, Vol. 13, No. 1

Lorenzo1, Olivas (2020) studied the history of stock markets as well as their impacts and the current effect of covid-19 outbreaks and pandemics occurring before stock markets. They propose to employ a provided model with Case-Based Reasoning (CBR): the 2008 crisis runs parallel to the CBR crisis by 2020, predicting how long the stock markets would need to recover. They conclude that current forecasting approaches are adequate when the trend is followed, but insufficient when a trend-breaking event occurs.

Sayed, O. A., \& Eledum, H. (2021). The purpose of this research is to examine the effects of COVID-19 on the Saudi stock market. Between 15 March 2020 and 10 August 2020, the daily shutdown prices index (TASI) of the Tadawul All Share Index and the number of cases infected with COVID-19 were used. The research is conducted using vector self-regressive (VAR), impulse response (IRF) and autoregressive heterogonic conditions (ARCH) models. The results of the correlation matrix and the Impulse Response Function (IRF) demonstrate a reactive effect from the financial markets in the epidemic on the growth. The results of the ARCH model show the detrimental influence on KSA stock market returns of the COVID-19 epidemic. Furthermore, the study suggested that the COVID-19 outbreak had a strong initial market reaction.

\section{Hypothesis}

$\mathrm{H}_{1}$ : There is significant association between Coronavirus total cases with Saudi Arabia's stock market return.

$\mathrm{H}_{2}$ : There is significant association between Coronavirus total death cases with Saudi Arabia's stock market return.

$\mathrm{H}_{3}$ : There is significant association between Coronavirus new cases with Saudi Arabia's stock market return.

$\mathrm{H}_{4}$ : There is significant association between Coronavirus new death cases with Saudi Arabia's stock market return.

\section{Model, Data Collection, Methodology, Empirical Findings}

Model: To analysis the impact of epidemic on Saudi stock market performance. We are applying least square regression model.

Stock Market return $=\alpha+\beta$ Coronavirus total cases $+¥$ Coronavirus total deaths cases + $\lambda$ Coronavirus new cases $+\gamma$ Coronavirus new deaths cases.

Coronavirus has been quantified in terms of cumulative new corona cases per million, new corona deaths per million, total corona cases per million, and total corona deaths per million, whereas stock market return has been quantified in terms of stock market index in this model.

\section{Data Collection}

To investigates the impact of COVID-19 epidemic on Saudi stock market performance time series data related to stock market was obtained from the https://www.investing.com/indices website, and daily data on COVID-19 was obtained from the https://ourworldindata.org official 
website of the Ministry of Health of the Kingdom of Saudi Arabia, which included all independent variables for the period beginning from 1 March 2020 to 6 Dec 2020.

Table 1. Descriptive analysis

\begin{tabular}{|c|c|c|c|c|c|}
\hline & $\begin{array}{c}\text { Stock } \\
\text { Market } \\
\text { Returns } \\
\end{array}$ & $\begin{array}{c}\text { New corona } \\
\text { cases per } \\
\text { Million }\end{array}$ & $\begin{array}{c}\text { New corona } \\
\text { death Per } \\
\text { Million }\end{array}$ & $\begin{array}{c}\text { Total corona } \\
\text { cases Per } \\
\text { Million }\end{array}$ & $\begin{array}{c}\text { Total corona } \\
\text { death Per } \\
\text { Million }\end{array}$ \\
\hline Mean & 7542.080 & 5685.600 & 73.84313 & 498253.9 & 5511.309 \\
\hline Median & 7427.335 & 7097.150 & 69.74800 & 284341.4 & 2306.439 \\
\hline Maximum & 8747.090 & 10303.74 & 171.3510 & 1603093. & 20594.46 \\
\hline Minimum & 5959.690 & 0.000000 & 0.000000 & 0.000000 & 0.000000 \\
\hline Std. Dev. & 735.8140 & 4081.255 & 62.89728 & 519387.1 & 6351.617 \\
\hline Skewness & -0.127376 & -0.303278 & 0.144277 & 0.654302 & 0.892457 \\
\hline Kurtosis & 1.958026 & 1.374039 & 1.422034 & 1.989485 & 2.422245 \\
\hline Jarque-Bera & 9.108975 & 23.84230 & 20.37148 & 21.64087 & 27.86444 \\
\hline Probability & 0.010520 & 0.000007 & 0.000038 & 0.000020 & 0.000001 \\
\hline Sum & 1432995. & 1080264. & 14030.19 & 94668240 & 1047149. \\
\hline $\begin{array}{l}\text { Sum Sq. } \\
\text { Dev. }\end{array}$ & $1.02 \mathrm{E}+08$ & $3.15 \mathrm{E}+09$ & 747696.7 & $5.10 \mathrm{E}+13$ & $7.62 \mathrm{E}+09$ \\
\hline Observations & 190 & 190 & 190 & 190 & 190 \\
\hline
\end{tabular}

Source: Author's calculation using EViews 12.

Result Analysis of Table 1 demonstrates mean, median, minimum and maximum values, standard deviation, skewness, kurtosis, Jarque-Bera, and number of observations. Mean means average value which is highest in case of Coronavirus total cases per million. Median means the middle value; Maximum and Minimum values are extreme value. Standard deviation is the most significant measurement for dispersion or spread over a series which is highest in total corona cases per million. Skewness measure negative values in case of Share market return and new corona cases per million means long tail on the left and When there is a positive value for new corona deaths per million, Total corona cases per million, and Total corona deaths per million, it indicates that there is a long tail on the right. Kurtosis results below 3 implies a flat (platykurtic) distribution in relation to normal distribution. Jerque-Bera can be used to test for normal distribution. As p-value (probability) which is $p<.05$, The null hypothesis is rejected in favor of the alternative hypothesis. 
Table 2. Summary of Regression Model

\begin{tabular}{|c|c|c|c|c|}
\hline \multicolumn{5}{|c|}{$\begin{array}{l}\text { Dependent Variable: Stock Market Returns } \\
\text { Method: Least Squares } \\
\text { Number of observations: } 190\end{array}$} \\
\hline \multirow[t]{2}{*}{ Variable } & Coefficient & Std. Error & $\mathrm{t}$-Statistic & Prob. \\
\hline & & & & \\
\hline $\begin{array}{c}\text { New Cases per } \\
\text { Million }\end{array}$ & 0.231299 & 0.059738 & 3.871911 & 0.0001 \\
\hline $\begin{array}{c}\text { New Death Per } \\
\text { Million }\end{array}$ & -39.4579 & 13.74961 & -2.869747 & 0.0046 \\
\hline $\begin{array}{l}\text { Total Cases per } \\
\text { million }\end{array}$ & 0.010856 & 0.003356 & 3.23435 & 0.0014 \\
\hline $\begin{array}{l}\text { Total death per } \\
\text { million }\end{array}$ & -0.537727 & 0.176072 & -3.054012 & 0.0026 \\
\hline $\mathrm{C}$ & 6695.207 & 34.10451 & 196.3144 & 0 \\
\hline & & & 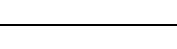 & \\
\hline R-squared & 0.891949 & Mean depe & nt var & 7542.08 \\
\hline $\begin{array}{l}\text { Adjusted R- } \\
\text { squared }\end{array}$ & 0.889612 & S.D. depen & at var & 735.814 \\
\hline S.E. of regression & 244.4715 & Akaike info & iterion & 13.86204 \\
\hline Sum squared resid & 11056767 & Schwarz c & rion & 13.94749 \\
\hline Log likelihood & -1311.894 & Hannan-Qu & criter. & 13.89665 \\
\hline F-statistic & 381.7872 & Durbin-Wa & n stat & 0.216087 \\
\hline Prob(F-statistic) & 0 & & & \\
\hline
\end{tabular}

Source: Author's calculation using EViews12.

Table.2 the Summary of regression model demonstrates that $\mathrm{R}$ square (Coefficient of determination) depicts that $89 \%$ of the dependent variable from independent variables that may be expected. Adjusted R-square, on the other hand, has a value of.889612, which is less than and quite near to $\mathrm{R}$ square 0.891949 . In comparison to predictors, the number of observations is fairly large. The standard error of regression (244.4715) measures estimated variance of the residuals. Probability (F-statistic) which is $p<.05$, we reject the null hypothesis in favour of alternative. On the basis of $\mathrm{P}$ value, we can say that there is significant association between corona total cases, corona total death cases, corona new cases and corona new death cases and stock market return of Saudi Arabia. Serial correlation measured by Durbin- Weston stat (.0216087), If the value is smaller than 2, there is evidence of positive serial correlation, according to the rule of thumb. Akaike info criterion is the lowest value as compare to Schwarz 
criterion and Hannan- Quinn criter. So, we can say that it is the best least square regression model to adopt in this study.

Table 3. Result of Pairwise Granger Causality Tests

Lags: 2

\begin{tabular}{|c|c|c|c|}
\hline Null Hypothesis: & Obs & $\begin{array}{c}\text { F- } \\
\text { Statistic }\end{array}$ & Prob. \\
\hline New cases per million does not Granger cause Share market return. & 188 & 7.21460 & 0.0010 \\
\hline Share Market return does not Granger cause New cases per Million & & 1.42307 & 0.2436 \\
\hline New death per million does not Granger cause Share market return & 188 & 7.79741 & 0.0006 \\
\hline Share market return does not Granger cause New death per million & & 1.22949 & 0.2948 \\
\hline Total cases per million does not Granger cause Share market return & 188 & 4.72253 & 0.0100 \\
\hline Share market return does not Granger cause Total cases per million & & 6.19920 & 0.0025 \\
\hline Total death per million does not Granger cause Share Market return & 188 & 3.61279 & 0.0289 \\
\hline Share market return does not Granger cause total death per million & & 7.85532 & 0.0005 \\
\hline
\end{tabular}

\section{Source: Author's calculation using EViews12.}

Table: 3 Analysis of Pairwise Granger Causality Tests: New cases per million granger cause Share market return since $P$ value is less than 0.05 but Share Market return does not granger cause New cases per million so there is unidirectional relationship. New death per million granger cause Share market return since $p$ value is less than 0.05 but Share market return does not Granger cause New death per million so there is a unidirectional relationship. Total cases per million does not Granger cause Share market return and Share market return does not Granger cause Total cases per million both cases $p$ value is less than 0.05 represent that there is bidirectional relationship. Total death per million does not Granger cause Share Market return and Share market return does not Granger cause total death per million both cases $\mathrm{p}$ value is less than 0.05 represent that there is bidirectional relationship.

Conclusion and Preventive Policies: The covid-19 affected almost all stock market around the world. Saudi Stock market also affected with Covid-19 Pandemic. The study found that the Saudi Arabian market responded quickly to the COVID pandemic, but that, according to the stage of the epidemic, the response was different with time. The Saud government has aided in mitigating the effects of the COVID-19 epidemic on the Saudi stock market by providing a speedy response time and a large stimulus package. Government COVID-19 preventive rules, in particular shutdown measures, have affected the stock markets, which in many financial institutions have disturbed decision-making, making fast reactions and trading impossible. Due 
to a lack of electronic infrastructure, certain financial institutions may be forced to close and traders may be unable to transact. Of course, their significance would reduce at least partially if a substantial proportion of commerce were automated and the economy technologically evolved; Consequently, potential impacts could be greater in emerging markets than in established countries. It is important mentioning that even if company premises are not completely shut down, soft rules can indirectly affect financial markets (Zaremba et al., 2021). In addition, COVID-19 policies can affect the stock market through policy reactions to changes in the future economic environment, and deteriorating economic conditions can lead to changes in corporate cash flow estimates and higher risk premiums, making investors less likely to do so by allocating their money to risky assets such as equities. Behavioural and psychological issues may affect investors. This means investors hesitate to investigate their holdings when there is adverse news about government constraints. Individuals with several successive loss episodes become more averse to loss. According to this school of thought, stock market trading activity falls (Zaremba et al., 2021). Saudi Arabia succeeds in minimizing transmission by restricting access to its Holy Sites at an early stage. Non-Saudi expatriates account for roughly 30.82 percent of Saudi Arabia's total population. Despite the fact that the main risk of illness transmission to asymptomatic evacuees remains, stringent action is being taken based on an assessment of the situation. The Saudi government's expertise in prevention strategies could help other countries deal with COVID-19 and similar pandemics. This article examines the impact of coronavirus on Saudi stock market performance by using regression model and pairwise granger causality tests. Results indicate that COVID-19 significant associated with Saudi stock market returns. The study also depicts that unidirectional and bidirectional relationship between corona-virus cases and Saudi stock market with the help of granger causality test.

\section{References}

Ahmar, A. S., \& del Val, E. B. (2020). Sutte ARIMA: Short-term forecasting method, a case: Covid-19 and stock market in Spain. Science of The Total Environment, 729, 138883. https://doi.org/10.1016/j.scitotenv.2020.138883

Alam, M. N., Alam, M. S., \& Chavali, K. (2020). Stock Market Response during COVID-19 Lockdown Period in India: An Event Study. The Journal of Asian Finance, Economics and Business, 7(7), 131-137. https://doi.org/10.13106/jafeb.2020.vol7.no7.131

Al-Najjar, H., Al-Rousan, N., Al-Najjar, D., Assous, H. F., \& Al-Najjar, D. (2021). Impact of COVID-19 pandemic virus on G8 countries' financial indices based on artificial neural network. Journal of Chinese Economic and Foreign Trade Studies, 14(1), 89-103. https://doi.org/10.1108/jcefts-06-2020-0025

Alsubaie, A., \& Najand, M. (2009). Trading volume, time-varying conditional volatility, and asymmetric volatility spill over in the Saudi stock market. Journal of Multinational Financial Management, 19(2), 139-159. https://doi.org/10.1016/j.mulfin.2008.09.002 
Anh, D. L. T., \& Gan, C. (2020). The impact of the COVID-19 lockdown on stock market performance: evidence from Vietnam. Journal of Economic Studies, 48(4), 836-851. https://doi.org/10.1108/jes-06-2020-0312

Arafa, A., \& Alber, N. (2020). The Impact of Coronavirus Pandemic on Stock Market Return: The Case of the MENA Region. International Journal of Economics and Finance, 12(12), 100. https://doi.org/10.5539/ijef.v12n12p100

Ashraf, B. N. (2020). Stock markets' reaction to COVID-19: Cases or fatalities? Research in International Business and Finance, 54, 101249. https://doi.org/10.1016/j.ribaf.2020.101249

Ashraf, B. N. (2020a). Economic impact of government interventions during the COVID-19 pandemic: International evidence from financial markets. Journal of Behavioural and Experimental Finance, 27, 100371. https://doi.org/10.1016/j.jbef.2020.100371

Baek, S., Mohanty, S. K., \& Glambosky, M. (2020). COVID-19 and stock market volatility: An industry level analysis. Finance Research Letters, 37, 101748. https://doi.org/10.1016/j.frl.2020.101748

Bentkowska, K. (2021). Response to governmental COVID-19 restrictions: the role of informal institutions. Journal of Institutional Economics, 1-17. https://doi.org/10.1017/s174413742100028x

Bora, D., \& Basistha, D. (2021). The outbreak of COVID-19 pandemic and its impact on stock market volatility: Evidence from a worst-affected economy. Journal of Public Affairs. Published. https://doi.org/10.1002/pa.2623

Chaouachi, M., \& Slim, C. (2020). Current COVID-19 Impact on Saudi Stock Market: Evidence from An ARDL Model. SSRN Electronic Journal. Published. https://doi.org/10.2139/ssrn.3636333

Christos, G., Charalambous, N., \& Eleni, K. (2021). Impact of COVID-19 on Stock Markets. Asian Economics Letters. Published. https://doi.org/10.46557/001c.22974

da Silva, R. G., Ribeiro, M. H. D. M., Mariani, V. C., \& Coelho, L. D. S. (2020). Forecasting Brazilian and American COVID-19 cases based on artificial intelligence coupled with climatic exogenous variables. Chaos, Solitons \& Fractals, 139, 110027. https://doi.org/10.1016/j.chaos.2020.110027

Elhini, M., \& Hammam, R. (2021). The impact of COVID-19 on the standard \& poor 500 index sectors: a multivariate generalized autoregressive conditional heteroscedasticity model. Journal of Chinese Economic and Foreign Trade Studies, 14(1), 18-43. https://doi.org/10.1108/jcefts-08-2020-0049

Fernandes, N. (2020). Economic Effects of Coronavirus Outbreak (COVID-19) on the World Economy. SSRN Electronic Journal. Published. https://doi.org/10.2139/ssrn.3557504 
Fernando, A. (2017). Macroeconomic Impact on Stock Market Returns and Volatility: Evidence from Sri Lanka. SSRN Electronic Journal. Published. https://doi.org/10.2139/ssrn.3238532

Gherghina, T. C., Armeanu, D. T., \& Joldeș, C. C. (2020). Stock Market Reactions to COVID19 Pandemic Outbreak: Quantitative Evidence from ARDL Bounds Tests and Granger Causality Analysis. International Journal of Environmental Research and Public Health, 17(18), 6729. https://doi.org/10.3390/ijerph1718672

Ghorbani, M., \& Chong, E. K. P. (2020). Stock price prediction using principal components. PLOS ONE, 15(3), e0230124. https://doi.org/10.1371/journal.pone.0230124

He, Q., Liu, J., Wang, S., \& Yu, J. (2020). The impact of COVID-19 on stock markets. Economic and Political Studies, $\quad 8(3), \quad$ 275-288. https://doi.org/10.1080/20954816.2020.1757570

Ibeaheem, H. A., Elawady, S., \& Ragmoun, W. (2018). Saudi Universities and higher education skills on Saudi Arabia. International Journal of Higher Education Management, 04(02). https://doi.org/10.24052/ijhem/v04n02/art05

Khan, K., Zhao, H., Zhang, H., Yang, H., Shah, M. H., \& Jahanger, A. (2020). The Impact of COVID-19 Pandemic on Stock Markets: An Empirical Analysis of World Major Stock Indices. The Journal of Asian Finance, Economics and Business, 7(7), 463-474. https://doi.org/10.13106/jafeb.2020.vol7.no7.463

Kırbaş, S., Sözen, A., Tuncer, A. D., \& Kazancioğlu, F. I. (2020). Comparative analysis and forecasting of COVID-19 cases in various European countries with ARIMA, NARNN and LSTM approaches. Chaos, Solitons \& Fractals, 138, 110015. https://doi.org/10.1016/j.chaos.2020.110015

Kompella, S., \& Chilukuri, K. C. (2019). Stock Market Prediction Using Machine Learning Methods. International Journal of Computer Engineering and Technology, 10(3). Https://Doi.Org/10.34218/Ijcet.10.3.2019.003

Kumarapperuma, O., Deyshappriya, N. R., \& Rajapakshe, M. (2021). The Impact of COVID19 on Stock Return in Asian Stock Markets Evidences from Developed, Emerging and Frontier Asian Markets. SSRN Electronic Journal. Published. https://doi.org/10.2139/ssrn.3847382

Lorenzo Sánchez, A., \& Olivas, J. (2020). Intelligent data analysis of the influence of COVID19 on the stock market using Case Based Reasoning. Journal of Computer Science and Technology, 20(2), e10. https://doi.org/10.24215/16666038.20.e10

Madai, T. B. (2021). Impact of COVID-19 Pandemic on Stock Market Returns. SSRN Electronic Journal. Published. https://doi.org/10.2139/ssrn.3794199

Mazur, M., Dang, M., \& Vega, M. (2020). COVID-19 and March 2020 Stock Market Crash. Evidence from S\&P1500. SSRN Electronic Journal. Published. https://doi.org/10.2139/ssrn.3586603 
Moreno, J. (2009). Trading strategies modeling in Colombian power market using artificial intelligence techniques. Energy Policy, 37(3), 836-843. https://doi.org/10.1016/j.enpol.2008.10.033

Nathan, T. M., Liew, V. K. S., \& Wong, W. K. (2016). Disaggregated Energy Consumption and Sectoral Outputs in Thailand: ARDL Bound Testing Approach. Journal of Management Sciences, 3(1). https://doi.org/10.20547/jms.2014.1603103

Olatunji, S. O. (2013). Forecasting the Saudi Arabia Stock Prices Based on Artificial Neural Networks Model. International Journal of Intelligent Information Systems, 2(5), 77. https://doi.org/10.11648/j.ijiis.20130205.1

Pothepalli, P. (2021). Stock Market Prediction: Using Econometric Models and Neural Networks. Global Journal for Research Analysis, 134-139. https://doi.org/10.36106/gjra/0113164

Rehan, M., Alvi, J., \& KARACA, S. S. (2020). Short Term Stress of COVID-19 on World Major Stock Indices. SSRN Electronic Journal. Published. https://doi.org/10.2139/ssrn.3663900

Rahman, M. L., Amin, A., \& Al Mamun, M. A. (2021). The COVID-19 outbreak and stock market reactions: Evidence from Australia. Finance Research Letters, 38, 101832. https:// doi.org/10.1016/j.frl.2020.101832

Sayed, O. A., \& Eledum, H. (2021). The short-run response of Saudi Arabia stock market to the outbreak of COVID -19 pandemic: An event-study methodology. International Journal of Finance \& Economics. Published. https://doi.org/10.1002/ijfe.2539

Sayed, O. A., \& Eledum, H. (2021b). The short-run response of Saudi Arabia stock market to the outbreak of COVID -19 pandemic: An event-study methodology. International Journal of Finance \& Economics. Published. https://doi.org/10.1002/ijfe.2539

SENOL, Z. (2020). Volatility Spill over Between Stock Market Sectors. Gazi Journal of Economics and Business, 6(3). https://doi.org/10.30855/gjeb.2020.6.3.003

Sansa, N.A. (2020). The Impact of the COVID - 19 on the Financial Markets: Evidence from China and USA. Electronic Research Journal of Social Sciences and Humanities, 2(2), 29-39. https://dx.doi.org/10.2139/ssrn.3567901

Saputra, G. E. F., Pulungan, N. A. F., \& Subiyanto, B. (2021). The Relationships between Abnormal Return, Trading Volume Activity and Trading Frequency Activity during the COVID-19 in Indonesia. Journal of Asian Finance, Economics and Business, 8(2), 737-745. https://doi.org/10.13106/jafeb.2021.vo18.no2.0737

Sharma, S. S. (2020). A note on the Asian market volatility during the COVID-19 pandemic. Asian Economics Letters, 1(2), 17661. https://doi.org/10.46557/001c.17661 
Shujan, S., Manamperi, M., Gowtham, P., Gooneratne, J., \& Sooriyaarachchi, N. (2020). Impact of covid-19 on stock market and growth of Sri Lanka. Available at https://www.researchgate. net/publication/341606800

Topcu, M., \& Gulal, O. (2020). The impact of COVID-19 on emerging stock markets. Finance Research Letters, 36, 101691. https://doi.org/10.1016/j.frl.2020.101691

Topaloglu, E. E., Ege, I., \& Koycu, E. (2021). Coronavirus (Covid-19) and Stock Market: Empirical Analysis with Panel Data Approach. International Journal of Economics and Finance, 13(3), 31. https://doi.org/10.5539/ijef.v13n3p31

Topcu, M., \& Gulal, O. S. (2020). The impact of COVID-19 on emerging stock markets. Finance Research Letters, 36, 101691. https://doi.org/10.1016/j.frl.2020.101691

Vijh, M., Chandola, D., Tikkiwal, V. A., \& Kumar, A. (2020). Stock Closing Price Prediction using Machine Learning Techniques. Procedia Computer Science, 167, 599-606. https://doi.org/10.1016/j.procs.2020.03.326

Waheed, R., Sarwar, S., Sarwar, S., \& Khan, M. K. (2020). The impact of COVID -19 on Karachi stock exchange: Quantile-on-quantile approach using secondary and predicted data. Journal of Public Affairs. Published. https://doi.org/10.1002/pa.2290

Wagner, A. F. (2020). What the stock market tells us about the post- COVID-19 world. Nature Human Behaviour, 4(5), 440-440. https://doi.org/10.1038/s41562-020-0869-y

Wren-Lewis, S. (2020). The economic effects of a pandemic. In Economics in the Time of COVID-19. London, UK: CEPR Press. https://voxeu.org/content/economics-time-covid-19

Wuhan Municipal Health Commission. (2019). Wuhan Municipal Health Commission on the current situation of pneumonia in our city. Retrieved April 29, 2020, from https://www.yicai.com/news/100452245.html

Yousef, I. (2020). Spill over of COVID-19: Impact on Stock Market Volatility. International Journal of Psychosocial Rehabilitation, 24(06), 18069-18081.

Zaremba, A., Aharon, D. Y., Demir, E., Kizys, R., \& Zawadka, D. (2021). COVID-19, government policy responses, and stock market liquidity around the world: A note. Research in International Business and Finance, 101359. https://doi.org/10.1016/j.ribaf.2020.101359

Zhang, D., Hu, M., \& Ji, Q. (2020). Financial markets under the global pandemic of COVID19. Finance Research Letters, 36, 101528. https://doi.org/10.1016/j.frl.2020.101528 